DOI 10.21868/PGnG.2016.2.4.

\title{
FROM FORMALISM TO MERIT: CIVIL SERVICE REFORM IN ROMANIA
}

\section{Victor Giosan ${ }^{1}$}

After its accession to the European Union on $1^{\text {st }}$ January 2007, one of the most important objectives of Romania has been the convergence with the rest of EU members not only in nominal terms, but also in real ones: competitiveness, wealth, poverty reduction, institutional capacity. Almost ten years after EU accession, we can say that significant progress has been realized in many areas, but in terms of institutional capacity Romania is facing the opposite of convergence: the divergence.

In the last 10 years, the institutional capacity gap between Romanian public governance and the "average" at the level of EU member countries increased - and one relevant indicator is the effectiveness of public investments (from both sources: national and EU). A very relevant graph, which shows this is the following - from IMF paper Benefits of Boosting Quality Public Infrastructure Spending in Romania (IMF Country Report, 2015), January 2015:

Figure 1.Efficiency of Capital Spending in the EU-28

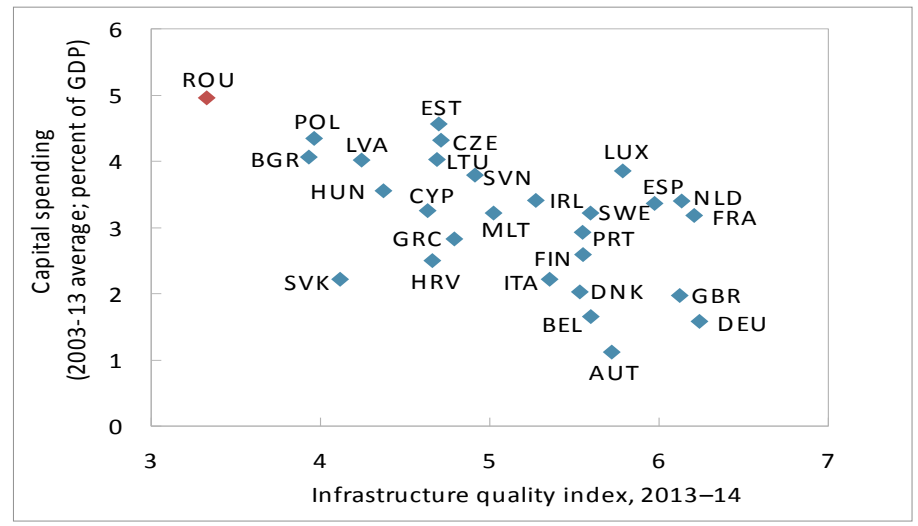

Source: Eurostat; World Competitiveness Report

What are the main reasons for this weakness in terms of institutional capacity? The first and main issue is the politicization of public administration - mainly the extension of a sort of neo-patrimonialism, where the appointments are decided on the basis of party affiliation (and within party to an interest group) and the main goal is the total or partial control of the public resource for personal gains. If we use Fukuyama's definition of patrimonialism characterized by kin selection and reciprocal

\footnotetext{
${ }^{1}$ Victor Giosan, State adviser on Prime Minster Chancellery in charge with public administration reform.
} 
altruism, the neo-patrimonialism means party/group selection and reciprocal services for the personal benefit (Fukuyama, 2011, 439).

The main tools used for this are: (i) chronic instability of the legal and institutional framework generated by ad-hoc and personalized regulation; (ii) exponential increase of different exceptions in the civil service legislation which have destroyed the rules, stability and predictability of the recruitment and promotion system, especially for the senior civil service positions; (iii) incoherent policies related to the human resource management in public administration, (iv) rigid behavior of the civil service, mainly generated by an over-formalism and legalism; (v) the civil service pay system is very fragmented and not performance-oriented.

The minimization of the merit in civil service recruitment and promotion system, together with legal framework confusion and fragmentation, ad-hoc and discretionary policy-making process and high level of instability for the top management position, can explain the retreat from formalism and legalism, as an expression of self-defense and reactive approach of the civil service. The regulation becomes a goal in itself, doesn't matter the results in resolving the problems, and has also the advantage to minimize the efforts of the civil servants.

\section{Civil service reform}

What solutions can have a technocratic cabinet to address all these issues? Technically, the proposed solutions address mainly the civil service. First, the stability and clarity of the institutional and legal framework. Secondly, to consolidate a central agency to manage the civil service - the National Agency of the Civil Service (NACS) which already exists from 1999. Thirdly, to change the recruitment, promotion and evaluation system and fourthly, to consolidate an evidence-based policy-making system together with a performance-based budgeting. There are few details to explain these reform steps.

a) The main proposal for improving the stability and clarity of the legal framework is to create a watch-dog institution, an independent council of the civil service, composed of 9 members ( 3 appointed by the President, 3 by Prime Minister and 3 by Parliament) selected by clear and transparent criteria on merit, relevant experience and non-political affiliation. The role of the council is to endorse the legislation addressing civil service, to monitor its implementation and to evaluate the situation of the civil service presenting an annual evaluation report to Parliament.

b) Regarding the management of civil service, it is absolutely necessary to increase and consolidate the role of NACS. Actually NACS is subordinated to the Ministry of Regional Development and Public Administration (MRDPA). Ideally, in my opinion, it should be located to 
the center of government (in Romania the Chancellery of the Prime Minister), because the mandate of the agency is essentially inter-sectoral and the authority and visibility of NACS should be much higher. For reasons of political economy this is not possible, but the role and the instruments of NACS will increase significantly in designing and implementing HR policies.

c) A key reform proposal addresses the recruitment, promotion and evaluation system. First of all, by 2019 all the civil service positions at central level will have occupational standards, detailing the necessary general and specific skills and the relevant experience. Starting from these occupational standards, the recruitment system will be drastically revised and a national competition system will be implemented, at least at central level, for the selection based on merit of the civil servants. For the top management positions, the selection will be realized in two phases: open competition based on occupational standards which will produce a short list and a second phase where the political decision maker (minister or state secretary) will appoint someone from this list. The intention is to limit the discretionary political decisions and to introduce a limited "legitimate" political influence, which exist in almost all administrative systems in developed countries. Another proposal is to eliminate the temporary holding of the top management positions, which now is hugely spread at central level - this is one of the most dangerous tools to extend the political influence. Finally, the evaluation system will be improved to connect the activity of civil servants (especially for the senior position) to measurable results reflected by clearly defined indicators.

d) The fourth area of interest is to extend the evidence-based policy making system by improving the procedures related to regulatory practices, generalizing the regulatory impact assessment (RIA) practice for major impact policies and regulations, increasing the specific capacity in ministries all these under strict supervision of the Chancellery of Prime Minister. In addition, it is necessary to really implement a performancebased budgeting, which can connect the results with resources on the whole chain of budget programming and execution on medium term ( $1+3$ years).

The implementation of policies in these four key areas has started at the end of June and will accelerate in autumn, but measurable results will not be obtained by end of this year, and this puts the critical problem of sustainability of the reform in the context of political framework. Unfortunately, from this perspective, the success is not so clear. First because the cabinet has a limited mandate, there is no clear support in Parliament and general elections will be organized in November or December 2016. Another key problem is the reluctance of political parties to support a decisive reform of the civil service, which have chances to 
drastically limit the practice of neo-patrimonialism - the main goal of "traditional" political activity. This is also linked with the internal reform of the actual parties or to the birth of new parties with this reform agenda.

List of References:

Fukuyama, F. (2011). The Origins of Political Order. From PrehumanTimes to the French Revolution. Profile Books, New York, 2011

IMF Country Report (2015). International Monetary Fund, Country Report No. 15/80, Romania, Selected Issues. March 10, 2015

OECD, Regulatory Impact Analysis

Webpage of Ministry of Regional Development and Public Administration

Webpage of National Agency of Civil Servants 